\title{
Conversion versus Ethnography: Adrien Gabriel Morice and the Western Dene
}

Daniel Sims, University of Alberta

\begin{abstract}
Conversion versus ethnography-how can one be both a missionary and ethnographer? Is there not an inherent contradiction between trying to radically change a culture and society through religious conversion, while simultaneously trying to "scientifically" record the same culture and society? Yet, many missionaries found themselves in the situation of attempting to preserve via their academic writings the very cultures and societies they condemned and sought to change in their religious career. This article is about one such missionary, Adrien Gabriel Morice, Oblate missionary to the Tsilhqot'in (Chilcotin), Dakelh (Carrier) and Tse Keh Nay (Sekani) of northern central British Columbia. It examines how he dealt with this inherent contradiction and concludes that not only did it hinder his conversion of First Nations, but also prevented him from making the academic move from Enlightenment ethnology to social Darwinism and Boasian anthropology. Nevertheless, despite the fact that this inherent contradiction cost him his mission post at Stuart Lake in 1903, Morice benefitted from his first-hand experience at that post and became influential as an ethnographer with regards to Dakelh social organization, religion, burial practices and gender. In this achievement, he was able to leave a lasting legacy despite the inherent contradiction between his role as a missionary and as an ethnographer.
\end{abstract}

\section{Introduction}

Adrien Gabriel Morice is a classic example of a missionary ethnologist; that is one who both worked to change his subject's culture via conversion, while at the same time academically recording and analyzing that which he sought to change. Understandably, this position led to internal conflicts for Morice as these oppositional goals competed for pre-eminence in his work and thinking. Underlying these competing goals were distinct ideological and philosophical principles and premises. Because of this, it is necessary to appreciate these principles and premises, and how they influenced Morice's life and work. This article will attempt to 
understand the influences that affected Morice as a missionary and as an ethnologist, and led to the internal conflict evident in his writings, and reflected in his life. I argue that this conflict hindered Adrien Gabriel Morice's work as a missionary, as his passion for ethnography took time and energy away from his primary goal to convert and civilize ${ }^{1}$ the Aboriginal peoples of the Interior of British Columbia. In addition, the empathy required as an ethnologist in understanding Aboriginal cultures made him less and less zealous to change these cultures and civilize them. Conversely, and perhaps ironically, Morice's Roman Catholic religious training and beliefs made him less able to understand Aboriginal culture in its own right. Further, as a missionary he was too conservative to adapt to newer trends that were changing the fields of ethnography and anthropology (social Darwinism and Boasian cultural relativism). Nevertheless, despite the inherent contradiction between Morice the missionary, and Morice the ethnographer, his first-hand experiences at his mission helped him leave a lasting ethnographic legacy. To understand how this conflict developed in Morice's life and work it is necessary to understand Morice's youth in France.

\section{Early Life and Influences}

The first influence that contributed to this conflict was Adrien Morice's education and upbringing in his native France. Born 28 August 1859 in Saint-Mars sur Colmont, in Mayenne, France, Morice grew-up during the Second French Empire of Napoleon III. The Roman Catholic Church was still recovering from waves of anticlerical sentiment that culminated during the early years of the French Revolution. In response to these attacks, Charles de Mazenod formed La Société des Missionnaires de Provence in 1815, which would later become known in 1825 as the Oblats de Marie

\footnotetext{
1 Throughout this article I refer to Morice's goal to civilize Aboriginal peoples. This, however, does not mean I believe that this is what he was actually doing. Rather, like all missionaries, Morice was merely trying to replace a pre-existing civilization with his own, a form of cultural colonialism.
} 
Immaculée. The Oblates, as they are known in English, were an ultramontane order; they placed great importance on the powers and prerogatives of the Pope, and as such were opposed to the laïcité, secularization, of the French state. Because of this, the Oblates sought to return the general population of France to the orthodox Roman Catholic fold, and consequently, revitalize the Roman Catholic Church in France. Although initially based in south-eastern France, the Oblate order quickly spread and by 1831 had expanded to overseas ministries, eventually establishing missions in British Columbia in 1858. Through these overseas missions, the Oblate's intended to spread Christianity and European civilization to local Aboriginal populations. ${ }^{2}$ This was to be accomplished within the conservative worldview of the Oblate order, a worldview that was instilled in Morice during his education in France.

In addition to this conservative worldview, changing events in France itself would influence Morice's education. In 1870, the Second French Empire collapsed following the decisive French defeat and the capture of Emperor Napoleon III at the Battle of Sedan, leading to the establishment of the Third French Republic. This was a major event for the Roman Catholic Church and Catholic orders in France, as the Third Republic saw the rebirth of French anti-clericalism. Fortunately for Morice, however, this anticlericalism remained largely rhetorical during his studies to become an Oblate priest. $^{3}$ Nevertheless, this rhetoric would hang like a storm cloud above the Oblate order, serving to reinforce it and Morice's conservative nature.

During his studies Morice was influenced to become an Oblate missionary and ethnologist. In September 1873, Adrien Gabriel Morice entered the Oblate Lesser Seminary in Mayenne. It was while studying at the seminary that Morice encountered Oblate missionary, Bishop Vital-Justin Grandin, who came to the seminary

\footnotetext{
2 Raymond Huel, Proclaiming the Gospel to the Indians and Métis (Edmonton: University of Alberta Press, 1996), 1-6.

${ }^{3}$ David Mulhall, Will to Power: The Missionary Career of Father Morice (Vancouver: University of British Columbia Press, 1986), 7.
} 
to recruit future missionaries for the Canadian Northwest. ${ }^{4}$ Grandin's influence on the young Morice was great, as seen in the latter's autobiography, where he states, "this is what I want! To work and suffer for souls, to battle among, and conquer, the lowly of America, that is my vocation." 5 This determination to become a missionary among the Aboriginal peoples of the Canadian Northwest would shape the remainder of Morice's studies in the seminary and stay with him for the rest of his life.

With this new determination and the career goal of being a missionary to Aboriginal peoples of the Canadian Northwest, Morice entered the Oblate Juniorate at Notre-Dame de Sion in 1874. It was here that during his study of the Oblate Missions ${ }^{6}$ that Morice discovered Father Emile Petitot, an Oblate missionary in the Canadian Northwest, who in addition to his work as a missionary was also recognized in the French ethnographic and anthropological community as an anthropologist, explorer, and linguist. Petitot's work had an impact on the young Morice and although he never directly stated it, it appears that his work, or rather the subsequent fame his work accrued, influenced Morice to become a missionary ethnologist. $^{7}$

In 1878, Morice became a brother in the Oblate order and entered the Oblate Scholasticate in Autun, Burgundy. It was here that he exhibited the first signs of the faults that would plague him throughout his career as an Oblate missionary: "vanity, ambition, and insubordination."8 Interestingly enough, these faults, although condemned by the Oblate order as against their desired lifestyle, fit with Terrence Craig's claim that "missionary service has not attracted cowards; it has attracted people with unusually strong wills as well as faith, and with the determination, discipline, and

4 Ibid., 2.

5 D.L.S., [Morice, A.G.] Fifty Years in Western Canada: Being the Abridged Memoirs of Rev. A.G. Morice O.M.I. (Toronto: The Ryerson Press, 1930), 6.

6 The Missions was an Oblate publication chronicling the career of Oblate missionaries. Mulhall, Will to Power, 4.

7 Ibid., 4.

8 Ibid., 6. 
intelligence to impose both their will and faith upon people they were prepared to love in advance of meeting them." ${ }^{\prime}$ Based on this observation, although his superiors in the Oblate order saw these traits as problems, they were ironically part of Morice's drive to become both a missionary, and an ethnologist, and contributed to his successes in both. Nevertheless, despite them, he was ordained as an Oblate priest on 9 October 1879. One of the main reasons for his ordination was connected to changes within the Third French Republic itself.

As already mentioned, during the majority of Morice's studies, the Third French Republic's anti-clericalism was largely rhetorical. This, however, began to change in 1877 with the constitutional crisis of the Sixteenth of May. Prior to this, the French Republic had been split between anti-clerical Republicans, who dominated the Chamber of Deputies, and Catholic Royalists who dominated the Senate and the Office of the President. This status quo was changed when the President of the Republic, Patrice de Mac Mahon, Duc de Magenta, attempted to install a Royalist Prime Minister, which resulted in the House of Deputies passing a vote of no-confidence, and the Senate subsequently dissolving the House of Deputies. In the resulting elections to the House of Deputies in 1877 and the Senate in 1879 , the Republicans not only kept their control of the House, but also took control of the Senate, giving them the power to implement policies previously held back by the Royalists, policies that included anti-clericalism and secularization. ${ }^{10}$ As such, what had once been rhetoric changed into action, and in 1880 anti-

\footnotetext{
9 Terrence Craig, The Missionary Lives: A Study in Canadian Missionary Biography and Autobiography (New York: Brill, 1997), 25.

${ }^{10}$ Historian Henri Martin was a French Senator from 1876 to 1883 . Presumably, the information found in chapters twenty-four and twenty-five of his A Popular History of France is based on firsthand knowledge. Georges Goyau, "France," http://www.newadvent.org/cathen/06166a.htm (accessed 11 March 2011); Georges Goyau, "Marie-Edme-Patrice-Maurice de MacMahon," http://www.newadvent.org/cathen/09504c.htm (accessed 10 March 2011); Henri Martin, A Popular History of France: From the First Revolution to the Present Time, vol. 3, trans. Mary Booth and A.L. Alger (Boston: Dana Estes and Charles E. Lauriat, 1882), chap. 24-25.
} 
clerical laws were passed.11 Minister of Public Instruction, Jules Ferry, began to expel religious figures from French schools and other public institutions, and the "Jules Ferry laws" established free, mandatory and laic education between 1879 and $1885 .{ }^{12}$ As a response to this anti-clerical sentiment, which threatened Oblate educational institutions, Morice was ordained early and sent to British Columbia on 26 June $1880 .{ }^{13}$ As to whether this was the sole reason, however, there is some debate. Some like David Mulhall argue that this was the only reason for Morice being ordained and sent to British Columbia. ${ }^{14}$ This view, however, was contested by Morice himself, who in his autobiography Fifty Years in Western Canada states, "Shortly after, his superiors showed that they had sufficient faith in him to dispose of him before the normal time, and, contrary to custom, they sent him out to foreign missions before he had been ordained."15 Given the fact, however, that Morice wrote this autobiography under the pseudonym DLS, and throughout it practiced wonderful examples of self-praise, this statement is questionable in regards to its truthfulness, especially considering the fact that de Mazenod, the founder of the Oblates, "deplored the hasty and incomplete formation of candidates for the priesthood." 16 This leads one to conclude that this statement is more wishful remembering than truth. This is seen by the fact that even in this example of self-praise, Morice is unable to ignore the role of the French state's anti-clerical laws in his being ordained and sent to British Columbia. Indeed, in the succeeding paragraph he states:

It is true that the civil authorities, then made up of atheists and so-called free thinkers, took great care to accelerate such a premature "obedience." It was in the spring of 1800 , when they trampled under foot

\footnotetext{
11 Mulhall, Will to Power, 7.

12 Christelle Garrouste, 100 Years of Educational Reforms in Europe: A Contextual Database (Luxembourg: European Union, 2010), 21-22, 201.

${ }_{13}$ Mulhall, Will to Power, 7.

14 Ibid., 7.

15 DLS, Fifty Years in Western Canada, 11-12.

16 DLS, Fifty Years in Western Canada, chap. 12, passim; Huel, Proclaiming the Gospel, 2.
} 
every principle of their pet Revolution slogan: Liberty, Equality, and Fraternity. They indeed granted liberty and equal rights to every association, provided it was an anti-Christian complexion; but religious Congregations they unmercifully dissolved, and confiscated their property. That was their mark of fraternity. ${ }^{17}$

Clearly, it would seem from this passage that Morice, although claiming that he was sent out prematurely, due to the faith his superiors had in him, was unable to ignore the fact that this was a reaction to the new anti-clericalism in France. Nevertheless, regardless of the exact reasons why Morice was sent to British Columbia in 1880, he went as a missionary ethnologist, who was not only influenced by the conservative ultramontane views of the Oblates, reinforced by the anti-clericalism of the French Republic, but also by the work and missions of Father Petitot and Bishop Grandin.

It was in British Columbia where he was introduced to the last concept that influenced his work as a missionary. Upon arriving in New Westminster on 26 July 1880, Morice was sent by Bishop Louis-Joseph d'Herbomez to St. Mary's, present day Mission City. As one of his first acts, Morice was sent to a local Squamish village to partake in a funeral. Here he was introduced to the Durieu system, developed by Father Pierre-Paul Durieu, which consisted of an early repression stage of conversion, policing, and punishment, followed by a secondary stage of moulding converts into ideal Roman Catholic Christians. ${ }^{18}$ This system was one of control over the Aboriginal population aimed at conversion and recreating European civilization. Its methods, however, were harsh, and indeed, it was later condemned by author Terrence Craig in The Missionary Lives who states, "This extreme, of missionaries presiding in fascist

17 DLS, Fifty Years in Western Canada, 12.

18 Mulhall, Will to Power, 8-9. 
authority in isolated areas is exceptional, even in the $19^{\text {th }}$ century." 19 Nevertheless, this system influenced Morice in his future missions to the Tsilhqot'in (Chilcotins) of the William's Lake area in 1883 and the Dakelh (Carriers and Babines) and Tse Keh Nay (Sekani) of the Stuart Lake area in 1885, and gave him a position of power in each, which aided him in his work as not only a missionary, but also as an ethnologist. ${ }^{20}$

In these missions, Morice's success and progress were directly related to the conflicts resulting from the influences of his education, life experiences, and role as both a missionary and ethnologist. With his Oblate background, and its ultramontane and anti-laïcité worldview, Morice strove to convert his subjects to orthodox Roman Catholicism, independent of the British Columbian colonial state and its regional agents. ${ }^{21}$ This ultramontane anti-laïcité view, however, conflicted with his desire to become an ethnologist, as these conservative views were in contradiction with contemporary anthropological views that at the time were transforming Enlightenment ethnology into Darwinist anthropology. This conflict negatively influenced Morice's work, not only as a missionary, but as an ethnologist too.

\section{The Missionary as Ethnographer}

Adrien Morice's mission among the Aboriginal peoples of the Interior of British Columbia was not as successful as his superiors would have liked. Morice saw himself as a missionary who was working to civilize and convert his subjects. In this role, he, like other missionaries, saw himself as the emissary between the colonial state, and the Aboriginal peoples with whom he worked. (In this, he was an agent of cultural colonialism.) Indeed, in his autobiography, he

\footnotetext{
${ }^{19}$ Craig, The Missionary Lives, 23.

20 DLS, Fifty Years in Western Canada, chap. 2.

21 Jennifer Brown, review of "Will to Power: The Missionary Career of Father

Morice" by David Mulhall” The American Historical Review 93, no.2 (1988): 530-531;

David Mulhall, Will to Power.
} 
claims to have prevented judicial errors from occurring against his flock. ${ }^{22}$ This, he claims, was recognized by the colonial state when he stated, following an incident with an overzealous Justice of Peace, that he:

Received from no less a party than Hon. Joseph Martin, who was then Attorney-General of British Columbia, a letter in which he stated how grateful the Government felt for all he had done to further the aims of justice in the North - a circumstance which betrays the fact that this was not the first instance of the priest helping to prevent judicial errors. ${ }^{23}$

Despite actively working to convert and protect his Aboriginal flock, Morice did not appear to be a successful missionary. This was because rather than civilizing his flock, he allowed them to retain their semi-nomadic hunting and trapping lifestyle, as well as their language, seeking to teach them neither English nor French, or to assimilate them. This "failure" can be largely attributed to his role as an ethnologist. According to David Mulhall, Morice neglected his duties as a missionary due to his efforts to further his knowledge as an anthropologist, explorer and linguist. Indeed, this secular preoccupation led to his failure to go beyond the first stage of regimental control in the Durieu system in his missions, and civilize his Aboriginal subjects. This failure to civilize his subjects not only alienated Morice from his fellow Oblate missionaries, who eventually refused to work with him, but also resulted in his unsuccessful request for aid from Bishop Augustin Dontenwill in 1900, and his eventual removal in $1903 .{ }^{24}$ Based on this, it is clear that Morice's role as an ethnologist negatively influenced his role as a missionary.

\footnotetext{
22 Craig, The Missionary Lives, 35; DLS, Fifty Years in Western Canada, 97; Mulhall, Will to Power, 132.

23 DLS, Fifty Years in Western Canada, 97.

24 Brown, review, 530-531; Mulhall, Will to Power, 4, 102-104, 119, 139, 156, 160 , 172-174.
} 
Despite this negative influence, however, Morice was nevertheless successful in converting his subjects to Roman Catholicism. In his article "Are the Carrier Sociology and Mythology Indigenous or Exotic?" published in 1892, he states "to-day all the Carriers and Chilkoh'tin are Roman Catholics." 25 This is not just mere self-glorification, and is confirmed by David Mulhall, in his critical biography of Morice, Will to Power. ${ }^{26}$ Morice was aided in conversion by the apparent openness and willingness of those to be converted. Morice himself alludes to this in his article "The Fur Trader in Anthropology: And a Few Related Questions" in which he states, "Perhaps the greatest characteristic of the Dene stock is its unparallel receptiveness." 27 He goes onto to state:

In the north, we cannot fail to remark that the receptiveness of that race are ever readily, nay eagerly, manifesting it in our own days by assimilating the religious notions of the whites and copying such of their manners as are consistent with the mode of life imposed on them by nature. ${ }^{28}$

This openness to European beliefs is similarly seen in his article "Notes Archaeological, Industrial and Sociological, on the Western Denes: With an Ethnographical Sketch of the Same" in which he states:

The Northern Denes, who are eminently gentle in disposition, have generally shown a remarkable receptiveness. And this explains how it is that, with few exceptions, they are all to-day practical

\footnotetext{
25 A.G. Morice, "Are the Carrier Sociology and Mythology Indigenous or Exotic?" Transactions of the Royal Society of Canada 2 (1892): 116.

26 Mulhall, Will to Power, $\mathrm{x}$.

27 A.G. Morice, "The Fur Trader in Anthropology: And a Few Related Questions," American Anthropologist 30, no.1 (1928): 74.

28 Ibid., 74.
} 
Christians, and conform to the customs of the whites as much as their social status will permit. ${ }^{29}$

Therefore, it would seem that the success of conversion (a cultural change) was aided, ironically, by the very culture Morice was tasked to change and which his ethnological work hindered from changing. Indeed, Morice himself acknowledges that this openness was one reason for his success in conversion.

Additionally was the fact that up to this point their contact with Europeans had been limited both in quantity and instructional quality. In this atmosphere of openness to European knowledge, and its previous absence, it is no wonder that his subjects willingly accepted the knowledge he brought them. This led Morice to teach more than mere Christianity, as is seen in his article "The Western Dene: Their Manners and Customs" in which he states:

Although the Denes, and especially the Carriers, literally crave for knowledge, yet, owing to the paucity of missionaries among them, religious instruction is about all that can be given them so far. In these latter years however, an effort has been made by the writer of this paper to teach them to read and write their own language, and the result has been wonderful. ${ }^{30}$

The origin of this phenomenon, Morice explained further is because "in spite of their shortcomings and of the weakness which they share with the rest of mankind, their motto is, and seems to have ever been, Sursum! Upwards."31 Therefore, based on the previous observation that Morice failed in his civilizing mission, it appears that conversion was largely due to the Western Dene's

\footnotetext{
${ }^{29}$ A.G. Morice, "Notes Archaeological, Industrial and Sociological, on the Western Denes: With an Ethnographical Sketch of the Same," Transactions of the Royal Society of Canada 4 (1893): 20.

30 A. G. Morice, "The Western Dene: Their Manners and Customs," Proceedings of the Canadian Institute 7, no.1 (1889): 165-166.

31 Morice, “Are the Carrier Sociology and Mythology Indigenous or Exotic?” 114.
} 
openness to it; in other words they self-converted, all he had to do was show-up and provide basic knowledge. Nevertheless, Morice is well situated within the corpus of missionary autobiographies, which portray their subjects as heroic. He maintains that Indigenous conversion was due to his own actions among the Western Denes. ${ }^{32}$ Indeed echoing this, I.S. MacLaren has claimed that Morice mistook their "openness to change for [their] tractability, naive simplicity, and... childish credulity," a claim that if true, would suggest Morice had an even bigger part in their conversion to Roman Catholicism then simply showing-up. ${ }^{33}$ Therefore, it seems that Morice was successful as a missionary in converting his subjects, not necessarily through his own efforts as a missionary, but rather because of the culture of the subjects of his ethnographic and missionary work.

\section{The Ethnographer as Missionary}

Just as Morice's work as a missionary was negatively influenced by his work as an ethnologist, so too was his ethnographic work influenced by his work as a missionary. This is important to remember as his ethnographic work was used not only in Roman Catholic works, such as the 1911 Catholic Encyclopedia, but also in academic works such as Diamond Jenness' Indians of Canada, and the Smithsonian's Handbook of North American Indians, to mention a few. ${ }^{34}$ In his work as an ethnologist, Morice was not only influenced

32 DLS, Fifty Years in Western Canada, chap. 12, passim; Craig, The Missionary Lives, 56,60 .

33 I.S. MacLaren, “'Caledonian Suttee?' An Anatomy of Carrier Cremation Cruelty in the Historical Record," BC Studies, no. 149 (2006): 30.

34 Glenda Denniston, "Sekani," in Handbook of North American Indians, vol. 6, ed. June Helm (Washington: Smithsonian Institution, 1981), 436-437, 440-441; Diamond Jenness, The Indians of Canada, 7 th ed. (Toronto: University of Toronto Press, 1977), 364, 382; Diamond Jenness, The Sekani Indians of British Columbia, no. 84, Anthropological Series, no. 20 (Ottawa: J.O. Patenaule I.S.O., 1937); A.G. Morice, "Chinooks," http://www.newadvent.org/cathen/03688a.htm (accessed 11 March 2011); A.G. Morice, "Denes," http://www.newadvent.org/cathen/04717c.htm (accessed 11 March 2011); A.G. Morice, "Hare Indians," http://www.newadvent.org/cathen/07136b.htm (accessed 11 March 2011); A.G. Morice, "Loucheux, " http://www.newadvent.org/cathen/09367b.htm (accessed 11 March 2011); A.G. Morice, "Nahanes,"

http://www.newadvent.org/cathen/10669b.htm (accessed 11 March 2011); A.G. 
by ethnographic and anthropological views of his time, but also by his theologically based Oblate education, which at the time included studies of neither. ${ }^{35}$ Because of this, conflicts beyond the amount of time spent on either arose between Morice's work as a missionary and as an ethnologist. Morice, for instance, was hardly unbiased in his studies of Aboriginal cultures, and like other missionaries saw Aboriginal cultures as being cowardly, materialistic, dishonest, unreliable, and opportunistic. Such views precluded the consideration of other worldviews, and therefore led to the devaluation and simplification of these cultures' tenets, as well as a failure to recognize their adaptive capabilities. ${ }^{36}$ Additionally, as David Mulhall states, Morice was unaware of his own biases and how they affected his work. ${ }^{37}$ This is clearly seen in his article "The Western Dene: Their Manners and Customs" in which he states:

I think I could, by ignoring some necessary exceptions, give them credit for relative morality, great honesty, intense fondness of their offspring and a general gentleness of disposition, not excluding, however, occasional freaks of irascibility. But to qualify these lines and give their true portrait, I should immediately add that they are prone to lying, addicted to gambling, naturally selfish, cowardly, and at times very lazy, especially the stronger sex. ${ }^{38}$

Clearly, therefore, Morice's education as an Oblate influenced his view of the Aboriginal cultures, among which he proselytized.

Morice, "Takkali," http://www.newadvent.org/cathen/14431b.htm (accessed 11 March 2011); Margaret L. Tobey, "Carrier," in Handbook of North American Indians, vol. 6, ed. June Helm (Washington: Smithsonian Institution, 1981), 413-415, 417419, 430-432. A more critical use of Morice's work is found in Guy Lanoue's Brothers and Daniel Sims' "Tse Keh Nay-European Relations and Ethnicity." Guy Lanoue, Brothers: Politics of Violence Among the Sekani of Northern British Columbia (New York: St. Martin's Press, 1982); Daniel Sims, "Tse Keh Nay-European Relations and Ethnicity," (MA Thesis, University of Alberta, 2010).

35 Huel, Proclaiming the Gospel, 2.

36 Craig, The Missionary Lives, 47-48.

37 Mulhall, Will to Power, 101.

38 Morice, “The Western Dene," 118. 
Furthermore, by describing these cultures in such negative terms Morice was not only reflecting missionary views, but also justifying missionary activities. ${ }^{39}$ This, however, created problems for him as an ethnologist, in terms of his ability to be unbiased in the examination of subject cultures.

Another area that affected Morice's work as both an ethnologist and a missionary was the conflict between Enlightenment and contemporary theories in ethnology and anthropology. At the time, observationally based and pseudoscientific Darwinist anthropology was replacing Enlightenment ethnology, which gave equal precedence to the Bible and philosophical text. Morice, however, fell into the ethnologist camp with its basis of knowledge consisting of the Bible, the classical literary and philosophical cannon and direct observation. ${ }^{40}$ This was not only because as a Roman Catholic missionary he was inherently not a modernist, but because the new anthropological theory was associated with fields supported by the Third Republic and revolutionary ideas to which the Oblates were opposed. ${ }^{41}$ Furthermore, as a missionary, Morice accepted the Bible as a literal source of information, an action that often led to conflicts between the Bible and his observations. ${ }^{42}$ Nevertheless, these observations, which were the basis of Darwinist anthropological studies, were found in Morice's ethnographic work, thereby making his work important to anthropologists.

Still, Morice was not part of the Darwinist anthropological school. This is clearly seen in his response to the conflict between Enlightenment monogenesis and Darwinist polygenesis. In following with the monogenesis tradition, Father Petitot argued that the Dene

${ }^{39}$ Craig, The Missionary Lives, 28; George Stocking, Jr., Victorian Anthropology (Toronto: Maxwell Macmillan Canada, 1987), 87-88.

40 Jane Samson, "Ethnology and Theology: Nineteenth-Century Mission Dilemmas in the South Pacific," in Christian Missions and the Enlightenment, ed. Brian Stanley (Richmond: Curzon Press Ltd., 2001), 100, 108.

${ }^{41}$ Craig, The Missionary Lives, 42; Brian Stanley, "Christian Missions and the Enlightenment: A Reevaluation," in Christian Missions and the Enlightenment, ed. Brian Stanley (Richmond: Curzon Press Ltd., 2001), 2; Stocking, Victorian Anthropology, 259.

42 Craig, The Missionary Lives, 71-72; Samson, "Ethnology and Theology," 121. 
were one of the Lost Tribes of Israel. Morice himself supported this view, despite that fact that he later criticized Petitot for his lack of supporting evidence. ${ }^{43}$ Because of this, Morice carefully concealed his beliefs in passing comments or in his footnotes, an act which made his ethnographic work more acceptable to Darwinist 149 anthropologists. ${ }^{44}$ Nevertheless, Morice maintained that the Dene were the product of some chain of events leading from the original Lost Tribes of Israel. This is seen when in 1906 he comments in The History of the Northern Interior of British Columbia that:

All we are prepared to state, after a careful survey of languages, manners and customs, is that: $1^{\text {st }}$, They are undoubtedly of a mixed origin; $2^{\text {nd }}$, they have come

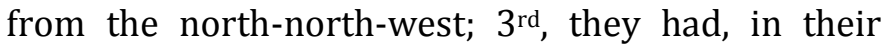
early history, commerce, perhaps through intermarriage, with peoples of Jewish persuasion or origin. 45

Similarly, these views are seen when he states that "in common with the Nazarenes of old, men and women parted their hair in the middle and wore it at full length." 46 Indeed, later in the same article he goes onto to state "thus it was that in the case of a deceased brother's wife, the Denes treated here conformably with the directions of the Jewish law, and the nephew considered himself in duty bound espouse her." ${ }^{47}$ In keeping with this verisimilitude between the customs and practices of the ancient Israelites, he later states that "the distinction between clean and unclean animals was a strictly defined among them as it was among the Jews." 48 Nevertheless, these practices were not identical to the ones of ancient Israelites. Morice rationalized this distinction by arguing that

${ }^{43}$ Craig, The Missionary Lives, 45; Mulhall, Will to Power, 101, 146.

${ }^{44}$ Mulhall, Will to Power, 101.

45 A.G. Morice, The History of the Northern Interior of British Columbia (Smithers: Interior Stationery Ltd., 1978), 7.

46 Morice, "The Western Dene," 115.

47 Ibid., 120.

48 Ibid., 164. 
the Dene became more uncivilized the further they travelled away from the Biblical lands, and had thus been changed by migration and intermarriage with non-Israeli groups. ${ }^{49}$ This is seen when he states in "The Western Dene" that, "On the other hand, having lost the knowledge of an only God through probable peregrinations among, and com-miscegenation with shamanistic Asiatic races, they have no constituted priesthood."50 Nevertheless, despite his clear belief in monogenesis, and as a result of his education, Morice did not easily fall into the Enlightenment ethnologist school of thought either.

That his views did not correlate with Enlightenment ethnologists is clearly seen in his dealing with the concept of the noble savage, an integral part of Enlightenment thought since Rousseau. Missionaries as a whole rejected the concept of the noble savage, due to the concept of original sin, and therefore the need of Aboriginal peoples to be saved by Christianity. ${ }^{51}$ Because of this, Morice's ethnographic work lacked the noble savage image he often portrayed in his popular works. For example in his popular work The History of the Northern Interior of British Columbia, he presents the Western Dene as noble savages versus ignoble Europeans. ${ }^{52}$ Even here, however, this was only related to the past, and Morice argues that the Dakelh are no longer the noble savages they once were. ${ }^{53}$ Clearly, therefore, although alluding to it in his popular works, Morice rejects the concept of the noble savage in his more numerous academic works, implying that he did not necessarily agree with concepts of Enlightenment ethnology.

49 Samson, "Ethnology and Theology," 109; Stocking, Victorian Anthropology, 152, 154.

50 Morice, “The Western Dene," 162n1.

51 Craig, The Missionary Lives, 42; Stanley, "Christian Missions," 9.

52 Morice, The History of the Northern Interior of British Columbia; Mulhall, Will to Power, 99, 165-166.

53 MacLaren, “'Caledonian Suttee?'” 29; David Mulhall, Will to Power, 37. 


\section{Morice's Influence as an Ethnographer}

Despite not fitting well into either scholarly assemblage, Adrien Morice was influential as an ethnographer and as a contributor to Darwinist anthropological studies. ${ }^{54}$ This was because his observations were valuable as anthropological information, a trait he shared with many other missionaries. ${ }^{55}$ Morice, however, was unique in that he actively sought to have these observations used as ethnological information. Indeed, he alludes to the importance of his observations in his article "On the Classifications of the Dene Tribes" in which he states:

It must be admitted that the opinion of such a scholar who personally knows the different tribes, should outweigh that even of travelers like Hearne and MacKenzie, who, for all their information, were entirely at the mercy of their interpreters and who were doomed occasionally to misunderstand and be misunderstood. ${ }^{56}$

In line with this view, he states in "The Fur Trader in Anthropology" that "the supposed assertion of a fur trader who could never understand a word of its language, and shields himself behind the personality of a more or less scrupulous half-breed for much of what he writes." 57 Adding to the importance of these observations was the fact that Morice was a skilled linguist, as was seen in his first mission among the Tsilhqot'in, in which he quickly learned their language. This is seen in his article "On the Classifications of the Dene Tribes" in which he states that, "when I was stationed among the Tsilkoh'tin I used to preach without an Interpreter. On my coming to Stuart's [sic] Lake, my residence since

54 This is cited earlier in the article with regards to the Catholic Encyclopedia, Indians of Canada, and Handbook of North American Indians, et al. in footnote 33.

55 Stocking, Victorian Anthropology, 234.

56 A.G. Morice, "On the classifications of the Dene Tribes," Transactions of the Royal Society of Canada 6 (1898): 76.

57 A.G. Morice, "The Fur Trader in Anthropology," 61. 
the last fourteen years, I could not understand or formulate a single sentence in Carrier." 58 Similarly in "Two Points of Western Dene Ethnography" he states:

When stationed among the Chilcotin in 1882-85, I learned enough of their dialect to freely converse with them and catechize them without an interpreter. But when, in August of the latter year, I came in contact with the Carrier of Stuart Lake, I could not understand a word of what they were telling me.59

His aptitude with Aboriginal languages continued at Stuart Lake, where despite not knowing the language on his arrival, he quickly learned it, which led him to state in his autobiography that:

One thing is certain. It was that mastery of the language he ultimately acquired which was to render him the king of the country, especially if we join that linguistic achievement to his great impartiality and his astonishing penetration of the Indian character as well as the instinctive sense he had of the probable results of a measure, or, of a direction on his people. 60

His ability to converse freely with local Aboriginal populations greatly contributed to the information in Morice's ethnographic works. In addition, because he was his only contemporary fluent in Dakelh, Morice served as a font of information on the Western Dene in the Interior of British Columbia. ${ }^{61}$ Because of this, Morice was influential in the anthropological studies of his time of the Aboriginal peoples of the Western Interior of British Columbia.

\footnotetext{
58 A.G. Morice, "On the classifications of the Dene Tribes," 77.

59 A.G. Morice, "Two Points of Western Dene Ethnography," American Anthropologist 27, no.3 (1925): 480.

60 DLS, Fifty Years in Western Canada, 47.

61 Brown, review, 530.
} 


\section{Dakelh Social Hierarchy}

Morice was influential as an ethnologist in regards to Dakelh social hierarchy. In his article "The Fur Trader in Anthropology" he describes the original social hierarchy of the Dene. He states that, "The original Dene were the most uncultivated, nay anarchistic, people one can imagine - with no government or even social organization to speak of."62 Accordingly, however, the Dakelh are different, because although "forming a Dene tribe, some of whose ethnical kindred are amongst the most primitive of people, through contact with a higher culture that of the Tsimshians of the western Coast, had endowed them with a more elaborate sociology."63 This contact resulted in dramatic changes among the Dakelh, and he states in his article "The Fur Trader in Anthropology" that:

As a consequence of such contact: $1^{\text {st }}$, the Babines and Carriers, to neglect other tribes, have partly abandoned their nomadic life to settle in fixed villages; $2^{\text {nd }}$, they have exchanged their traditional patriarchate for the matrilineal form of government prevailing among their western neighbours; $3^{\text {rd }}$, they have adopted all the consequent institutions flourishing among the latter: hereditary petty chiefs, or noblemen (toeneza) wearing peculiar ear-rings, the potlatch and attendant festivities, ceremonial dances and theatrical representations, as well as the cremation of the dead-all formerly unknown to other Dene of the north. ${ }^{64}$

In his article "Are the Carrier Sociology and Mythology Indigenous or Exotic?" he elaborates on social hierarchy, stating:

62 Morice, "The Fur Trader in Anthropology," 71.

63 A.G. Morice, "Carrier Onomatology," American Anthropologist 35, no.4 (1933):

633.

64 Morice, "The Fur Trader in Anthropology," 75. 
They were divided in two very distinct social classes: the hereditary nobles, or notables, who possessed the land and enjoyed many jealously-guarded privileges, and the common people who had no voice in the councils of the nation and acted as serfs to the notables with who, and for whom they hunted.... The rank of such personages was obtained and sustained through that famous institutions familiar to the Indians of the whole North Pacific coast, the "potlatch," or public distributions of victuals and goods, which was made by the aspirant or received notable, with the help, generally, of all the members of his particular clan.... For, as among the maritime Indians, the Carriers were also divided into several clans or gentes, which originated, in their estimation, a relationship closer and more binding than that resulting from blood parentage.... The kinship resulting from fellowclanship was reputed to be so strict that it precluded the possibility of co-clansmen intermarrying, while, on the other hand, marriage between even first cousins, if on the mother's side, was quite common, and, in some cases, almost obligatory. By an immemorial custom, the widow of a Carrier was also inevitably transferred as wife to the deceased's surviving brother.... The death of a member of the tribe, especially of a nobleman, was seized upon as a pretext for interminable lamentations on the one side and ostentations feasting and banquetting [sic] on the other. ${ }^{65}$

Furthermore, according to him the death of a notable resulted in an elaborate succession process. In his article "Carrier Onomatology" he states:

When therefore, a nobleman or notable dies, it is well understood that he will be succeeded by the eldest, or another, son of one of his sisters, who belong to same gens as himself, inasmuch as land cannot be alienated

65 Morice, “Are the Carrier Sociology and Mythology Indigenous or Exotic?” 111-112. 
into a strange social division; but that succession cannot be effected without paying for it, and the way to do this consists of a series of public feasts or donations, six in number, which I expounded with details as long ago as 1888.66

This was an important observation since he argued that the Dakelh differed from their fellow Dene by having matrilineal lines of descent. In "The Fur Trader in Anthropology" he states:

With all the eastern Dene the patriarchal system is in vogue, while matriarchy, copied from the adjoining tribes, obtains among the semi-sedentary branches of the family, which live in close contact with the villagers of the Pacific coast and coterminous aborigines. On the one hand, the patriarchy of nomadic bands with hardly any social organization, not even real chiefs; on the other, hereditary matrilineal chiefs and noblemen with distinctive insignia, ceremonial feasting and cremation of the dead instead of aerial burying, labretifery [sic], histrionic masks and other customs proper to more or less sedentary people. ${ }^{67}$

According to him, this, along with the rest of Dakelh social hierarchy, was a product of contact with the Tsimshian. Furthermore, he considered it part of a higher society than the primitive Dene and he states, "To patriarchy as obtaining among the unadulterated Dene. Matriarchy, on the other hand, is consequent on a higher state of society, on more important groupings of less nomadic human beings."68 Not only does this statement reflect the Victorian era debate over matriarchies and patriarchies, but Morice also states that in his view this form of social structure (the

66 Morice, "Carrier Onomatology," 640.

67 Morice, "The Fur Trader in Anthropology," 73-74.

68 Ibid., 73. 
matriarchy) was a consequence of the lack of Christianity among the Dakelh. ${ }^{69}$ In his article "The Fur Trader in Anthropology" he states, "Daily familiarities between the sexes often degenerates into promiscuity and a time comes when even the real paternity of children becomes a matter of doubt."70 Based on this, Morice's views, although important as a primary source on social hierarchy among the Dakelh, are nonetheless influenced by his role as a missionary.

\section{Dakelh Religion}

A second area in which Morice was influential as an ethnologist was in regards to Dakelh religion. In his article "The Western Dene" in describing their religion he states:

Apart from the superstitious dances..., the Western Denes observed no religious ceremonies. They made no sacrifices, worshipped no Deity and had no definite cultus unless we dignify with that name the shamanism of the Northern Asiatic races, which obtained among them. True, they vaguely believed in a kind of impersonal and undefined Divinity, not quite pantheistic; but rather more so than individual, almost co-essential with the celestial forces, the cause efficient of rain and snow, winds and other firmamental phenomena. They called it Yuttoere ("that which is on high") in Carrier. But they did not worship this power-they rather feared it and endeavoured to get out of its reach, or, when this was impossible, to propitiate it and the spirits who were supposed to obey it, with the help and through the incantations of the nelhgen or conjuror. This shaman was credited, when exercising his mysterious arts, with the power of controlling the coming or

69 Stocking, Victorian Anthropology, 205.

70 Morice, "The Fur Trader in Anthropology," 73. 
departing of evil spirits. Even when not actually conjuring, he was believed to be able to kill by his mere will any objectionable person.... The Denes believed man to be vivified by a soul, which to them was nothing else than his natural warmth (nezoel) and which as such died with the body. But besides this, they credited every human being-indeed many still hold to that belief-with the possession of another self or shade (netsin), which was invisible as long as he enjoyed good health, but appeared wandering about in one form or another whenever disease or death was imminent.... Whenever the moribund lay unconscious they believed his double to have departed for the land of the shades or spirits, though after death it received another name (nezul) and was then supposed to be the impalpable form of the man's previous self. We thus see that the immortality of the soul, though in an imperfect manner, was admitted by these people.... ${ }^{71}$

This passage is a clear example where Morice both records Dakelh religious beliefs, and denies their religiosity, a trait common to many missionaries of his time. ${ }^{72}$ Similarly, in a following passage Morice exposes himself as a missionary, by talking not only of original truths, but of also comparing Dakelh observances to Mosaic ones, and by so doing, according to David Mulhall, comes dangerously close to directly and openly affirming his belief that the Western Dene are one of the Lost Tribes of Israel. ${ }^{73}$ In the passage he states:

Closely related to a people's religious beliefs are their superstitious observances, and, as a rule, the more the former have deviated from original truths, the

\footnotetext{
71 Morice, “The Western Dene," 157-159.

72 Craig, Missionary Lives, 34.

73 Mulhall, Will to Power, 101.
} 
more will the latter be found to have developed both in number and relative consideration.... Prominent among these are the observances peculiar to the fair sex, and many of them are remarkably analogous to those practiced by the Hebrew women, so much so that, were it not savouring of profanity, the ordinances of the Dene ritual code might be termed a new edition "revised and considerably augmented" of the Mosaic ceremonial law. ${ }^{74}$

Clearly, Morice's contributions to the ethnographic literary corpus on Dakelh religion are directly influenced by his role as a missionary; nevertheless, they are still a rich ethnographic source.

\section{Dakelh Cremation}

Morice was also influential as an ethnologist in regards to Dakelh cremation. This is an interesting topic for Morice to cover, as even he admits that it had "long been abolished."75 As a result, this section of Morice's work is entirely dependent on the accounts of fur traders. ${ }^{76}$ According to him, the custom was borrowed from the Tsimshian. In his article "Are the Carrier Sociology and Mythology Indigenous or Exotic?" he states:

When the former came in contact with the Tsimshian races they could not fail to notice that cremation was practiced by them, and at the time of the discovery of their country all the subdivisions of their tribe burnt their dead and erected for the few remaining bones mortuary column identical with those in vogue among the Tsimshian. ${ }^{77}$

\footnotetext{
74 Morice, “The Western Dene," 161-162.

75 Morice, "Are the Carrier Sociology and Mythology Indigenous or Exotic?" 111.

76 MacLaren, “'Caledonian Suttee?'” 31, 34.

77 Morice, “Are the Carrier Sociology and Mythology Indigenous or Exotic?” 121.
} 
Thus, it was this practice that led to the Dakelh acquiring their English name Carrier. This is seen in his article "Two Points of Western Dene Ethnography," in which he states, "Now these Sekanai called their immediate Western neighbors Arelne, Carrier, from the custom of their widows to daily "carry" on their backs the bones of their late husband whose remains had been cremated."78 Just as it was acquired through contact with another cultural group, so too was it abandoned. He states earlier in the article that, "So they acted with regard to the cremation of the dead, which, to imitate the whites, they replaced by interment, and that so soon and so spontaneously that I doubt whether there now lives among them an eye-witness of the traditional ceremony."79 This is another example of Dakelh openness to change, as cremation's absence from the cultural-religious practices of the fur traders led to its ending among the Dakelh. ${ }^{80}$ Nevertheless, Morice is captivated by Dakelh cremation and Dene burial practices, stating that, "I have seen with my own eyes some of the scaffolding on which the former's dead rested, not less than a few of the funeral posts supporting the boxes which contained the charred bones which had escaped the action of the flames in the course of Carrier cremation." ${ }^{81}$ Part of this fascination can be explained by the fact that Christianity with its notions of corporeal sanctity was opposed to cremation. ${ }^{82}$ This is clearly seen in his account of the role of the widow or widower in the cremation process. In his article "The Western Dene" he states:

Thenceforth hers was a miserable lot indeed. From the very moment of her husband's decease to the time (two or three years later) of the final giving away of property in his honor, she was the slave of her brothers-in-law and sisters-in-law, one of whom would at once cut her hair to the roots and take care

\footnotetext{
78 Morice, "Two Points of Western Dene Ethnography," American Anthropologist 27, no.3 (1925): 481.

${ }^{79}$ Morice, "Are the Carrier Sociology and Mythology Indigenous or Exotic?" 115.

80 MacLaren, “'Caledonian Suttee?'” 31.

81 Morice, "The Fur Trader in Anthropology," 70.

82 MacLaren, “'Caledonian Suttee?'” 4. 
to renew the operation whenever needed as a badge of the abject condition of her widowhood. She was also obliged to wear ragged clothes, and in case she was young and likely to re-marry when the period of mourning ceased, decency constrained her to pollute her face with gum lest her guardians (so they were called) should suspect her of desires unsuited to her condition.... Men who had lost their wives were obliged to undergo the same ordeal, though treated somewhat more humanely than the weaker sex. When the future successor of the dead notable had succeed in gathering a goodly amount of dressed moose and other skins and provisions, the inhabitants of all the surrounding villages were invited to witness the cremation of the corpse. The funeral pile being kindled in the outskirts of the village by men not belonging to the deceased's clan (who were paid on the spot by the latter's relatives) the widow as obliged by custom to embrace the remains of her late husband even though surrounded by flames, amidst the howlings and wailings of his fellow-clansmen. When momentarily withdrawn by the bystanders, etiquette demanded from her repeated endeavours to burn herself along with the remains. Supposing she had not been a good wife, she was in many cases jostled by the mourner, and sometimes horribly disfigured with the view to diminish her chances of re-marriage.... Among the Carriers, the late notable's relations would, on the morrow, while shedding many a dutiful tear, carefully pick up from among the ashes of the pyre, the few remaining charred bones and hand them to the widow, who would, till the time of her liberation form 
widow's bondage, constantly pack or carry them in a small satchel. ${ }^{83}$

Indeed, the cruelty of this practice caused Morice to wonder why it was not stopped sooner. ${ }^{84}$ It was not stopped, in part, because

Morice, already biased by his Christian views on cremation, was possibly deceived by the fur trader records. This has long been argued by the Dakelh themselves, and indeed Lizette Hall has called into question both the practice of maltreating widows and widowers, as well as the carrying of bones of their husband by them, because as she recounts not one Dakelh elder remembers the practice of either. ${ }^{85}$ Based on this, Morice's views, although important as a source of Dakelh cremation, are nonetheless still influenced by his role as a missionary, as seen in his portrayal of cruelty to widows and widowers.

\section{Dakelh Gender Roles}

A final area in which Morice was influential as an ethnologist was in regards to Dakelh gender roles. This area is clearly influenced by Morice's role as an ultramontane Oblate missionary. Indeed he clearly states this in his article "The Western Dene" when he states:

I need hardly say that among the Denes the status of woman after marriage was seldom preferable to her previous conditions. For I take it to be granted that among most of the non-Christian peoples of the day, as well as the various nations of antiquity, woman, under one form or another is, and has ever been, very little short of her land and master's slave. ${ }^{86}$

\footnotetext{
83 Morice, “The Western Dene," 145-146.

84 Morice, The History of the Northern Interior of British Columbia, 91.

85 MacLaren, “'Caledonian Suttee?'” 24-25.

86 Morice, "The Western Dene," 123.
} 
According to him, life in the typical Dakelh family matched this description. Morice states that "we see the wife working as a slave, without exercising any authority (unless by exception, she were a notable), and the husband domineering as her lord and master and having in hands the full administration of the family affairs." ${ }^{87}$ Following on this vision of the typical Dakelh family, in his article "The Western Dene" he states:

Then her lot is to pack all the family impedimenta, while her husband, gun in hand, gaily precedes her on the way trying to have an occasional shot at game to diversify the menu of the evening meal. However, let us not pity her beyond measure, for as she never knew or even dreamt of a better fate she does not murmur herself, neither does she ever complain of her husband's ungallant conduct. Besides, her ability for this kind of labor has been developed from childhood, since among the natives even the little ones are trained to carry some of the family goods and chattels.... It would however, be wrong to conclude that her daily toil is over when at dusk the couple stops for the purpose of camping. Then all the work in the way of gathering firewood, erecting the temporary lodge, cooking, etc., must be attended to by her, the man's duties and attributes among the Denes, when in their primitive state, being restricted to hunting, eating and sleeping. 88

Additionally, Morice describes how the Dakelh had once been polygamous, although this ended with the fur trade; yet another example of Dakelh openness to change. In his article "Are the Carrier Sociology and Mythology Indigenous or Exotic?" he states:

\footnotetext{
87 Morice, "Are the Carrier Sociology and Mythology Indigenous or Exotic?" 112.

88 Morice, "The Western Dene," 124. 
Polygamy flourished here as on the coast, and marriage, though somewhat difficult of attainment for the young man, was never considered as indissoluble.... As the foreign traders had only one wife, the natives, who seemed to have but one ambition - that of raising themselves to the standard of their social superiors - abandoned polygamy even before any minister of religion had set foot among them. 89

Nevertheless, this gender role, even without polygamy, was inappropriate to Morice who saw it as misogynistic. ${ }^{90}$ Because of this, and using Victorian-era marriage as a standard, Morice aimed at ending Aboriginal female servitude. ${ }^{91} \mathrm{He}$ argued that this practice was just another sign of Dene degradation from their ancient Israeli ancestors and therefore needed to change as they re-embraced Christianity. ${ }^{92}$ Based on this, Morice's views, although important as a source on Dakelh gender roles, are nonetheless still influenced by his role as a missionary.

\section{Conclusion}

Adrien Gabriel Morice was the archetype of a missionary ethnologist. Working as both a missionary and as an ethnographer, he was forced to try to reconcile the conflicts that arose from the underlying concepts and premises of each. This conflict negatively influenced his mission work, and was based first, on his Oblate ultramontane, anti-laïcité education, second, on the anti-clericalism in the Third French Republic, which reinforced this education, and third, on the Durieu system of the West coast, all of which were opposed by the ethnographic concepts and premises from his

\footnotetext{
${ }^{89}$ Morice, "Are the Carrier Sociology and Mythology Indigenous or Exotic?" 112, 115. 90 MacLaren, “'Caledonian Suttee?" 23.

91 Mulhall, Will to Power, 72; Stocking, Victorian Anthropology, 205-206.

92 Stocking, Victorian Anthropology, 90.
} 
ethnographic work. Because of this, as a missionary he succeeded in converting his subjects, (largely due to their openness to change) but failed to civilize them, (largely due to his role as an ethnographer) and as a result he was removed from his post at Stuart Lake in 1903. As an ethnographer, Morice was more successful. Based on the prevailing intellectual climate, Morice was a Biblical ethnographer, who did not fit well with either Enlightenment ethnologists or Darwinian anthropologists. Nevertheless, his observations were valuable to both fields and this was the main reason that contributed to his success as an ethnologist.

His ethnological work was influential in four areas and was also influenced by his role as a missionary ethnologist. His views on Dakelh social hierarchy were influenced by the values and morals of the time in which he lived. Similarly, his views on Dakelh religion are textbook examples of missionary views of Aboriginal religions, in that he dismisses them as mere superstitions and not actual religions. Similarly, in regards to Dakelh cremation, Morice expresses the Christian view that it is barbaric, especially in regards to the treatment of widows and widowers, a view challenged by Dakelh scholar Lizette Hall. Finally, in regards to Dakelh gender roles, Morice uses Western European practices to not only to judge Dakelh gender roles, but also to attempt to change them from what he considered to be an example of Dakelh degeneration from the their ancient Israel origins. Despite the conflicts that arose from his role as missionary and ethnographer, Morice was influential as a missionary ethnologist. This was not only because his work was based on first-hand experiences, but also because of his knowledge of Western Dene languages. Although a failure in terms of his 'civilizing mission', his knowledge of their language and culture, helped him succeed in converting the Western Dene to Roman Catholicism, an action greatly aided by their openness to change. In this way, although his dual role as missionary and ethnologist often conflicted, he succeeded at both, in ways unexpected by his Oblate superiors. Though he was considered idealistic and in some ways a 
failure as a missionary, his superiors tolerated him so that his successes could become their successes. 